\title{
Results of Comparative Studies of Tillage Technologies When Sowing Repeated Crops
}

\author{
Ergashev I. T. \\ Doctor of Technical Sciences, Professor \\ Islomov Yorqin $(\mathrm{PhD})$, \\ Pardaev Kh. K. \\ Applicant, \\ Toshtemirov B.R. \\ Applicant, \\ Ismatov A. \\ Doctoral Student,
}

\author{
Abdullaev B. \\ Doctoral Student
}

\begin{abstract}
ANNOTATION
The article presents the main results of comparative experimental studies of traditional (plowing, chisel-growing) and energy-saving (strip) tillage in Uzbekistan when sowing re-crops after harvesting winter cereals.

Keywords: tillage, plowing, chisel-growing, strip tillage, repeated (intermediate) crops, water consumption, yield.

\section{INTRODUCTION}

The main and most promising direction of the development of agriculture at the present time is its intensification. At present, much attention is paid to the rational use of available land resources. Most of the main crops of crop rotation in farms occupy fields, with the duration of the total period of possible vegetation of plants $50-70 \%$. The remaining 30-40\% of agro-climatic resources must be rationally used, which is of particular relevance on the irrigated lands of Uzbekistan.

Re-sowing is a significant additional source of agricultural crops cultivation, which allows increasing agricultural production and will also provide the population with food. Cultivation of repeated, intermediate crops, allows you to get two crops per year from one land area [1].

The rational use of irrigated arable land provides for the cultivation of crops throughout the growing season, since nature does not like emptiness. In irrigated agriculture, intermediate (repeated) sowing of legumes and other crops helps to solve this problem [2].
\end{abstract}

\section{ANALYSIS OF EARLIER STUDIES}

A new direction of soil cultivation in our country - its maximum possible minimization - began in the 60s of the last century. In this regard, extensive research has been carried out at the Uzbek Cotton Research Institute (UzPTI), the Institute of Extreme Plant Biology, and the Scientific Research Institute for Mechanization and Electrification of Cotton.

V.P.Kondratyuk, A.K.Kashkarova, Z.S. Surunkhodzhaev, K. Mirzhaionov, S. Saidumarov, Z. Umarov, Y. Abenov, S. Abinov worked in various soil and climatic conditions of the republic, studies were carried out to minimize such measures as preparation for sowing $[3,4,5,6]$.

Khasanova F., Esonbekov Y., Khasanov M. et al. Believe that repeated and intermediate sowing of agricultural crops on irrigated lands after grain is one of the important conditions of the system of intensive farming, which plays a key role in improving soil fertility, ecology, food and feed. ... When crops are grown in full accordance with scientifically grounded correct crop rotation technology, soil fertility and its agrochemical, agrophysical, microbiological properties are preserved [7].

Based on the data presented by A.A. Iminov, N. Khalilov, M. Atamuradova, it can be concluded that changes have been made to the structure of agricultural crops. In farms with modified crop rotation systems, the 
introduction of short-term crop rotation systems after winter wheat, legumes and soybeans as a secondary crop allows the collection of an average of 5.97-6.54 tons of organic waste per hectare per year. Provides biological accumulation of nitrogen in the amount of $37.8-41.3 \mathrm{~kg} / \mathrm{ha}$, phosphorus in the amount of $12.8-19.8 \mathrm{~kg} / \mathrm{ha}$, potassium in the amount of $22.6-30.9 \mathrm{~kg} /$ ha [8].

F. Hasanova, A. Khaidarov, S. Bakhromov noted that different methods of tillage after wheat create a different agrochemical composition of the soil, creating a unique soil environment for plant growth and development, i.e. repeated corn without tillage, in the sowing variant the humus content was $0.92 \%$, and the nitrate content was $8.31-9.72 \mathrm{mg} / \mathrm{kg}$. Also, in the variant of multiple sowing of maize plowed $22-25 \mathrm{~cm}$ after wheat, the nutrient content was $1.06-1.09 \%$ and $11.1-12.3 \mathrm{mg} / \mathrm{kg}$, respectively, the humus content was $0.14-0$, $17 \%$, nitrates gave more than $2.5-2.8 \mathrm{mg} / \mathrm{kg}$, creating favorable conditions for normal growth and development of plants. In variants plowed in summer after wheat, nutrients were the lowest [9].

In the study of Khasanov F.M., Karabaev I.T. by the end of the shelf life of maize sown as a secondary crop, the soil density was $1.22 \mathrm{~g} / \mathrm{cm} 3,1.26 \mathrm{~g} / \mathrm{cm} 3,1.29 \mathrm{~g} / \mathrm{cm} 3$ and $1.30 \mathrm{~g} / \mathrm{cm} 3$ in the version treated with a chisel on depth of $16-18 \mathrm{~cm}$, and 1 in the variant treated with a cultivator to a depth of $8-10 \mathrm{~cm} .28 \mathrm{~g} / \mathrm{cm} 3-1.29$ $\mathrm{g} / \mathrm{cm} \mathrm{3,} \mathrm{that} \mathrm{is,} \mathrm{with} \mathrm{repeated} \mathrm{sowing} \mathrm{in} \mathrm{summer,} \mathrm{an} \mathrm{adverse} \mathrm{effect} \mathrm{on} \mathrm{the} \mathrm{agrophysical} \mathrm{state} \mathrm{of} \mathrm{the} \mathrm{soil} \mathrm{(0-30}$ $\mathrm{cm})$ tillage by various methods was not observed [10].

Experiments have shown that high yields are obtained by plowing the soil to a depth of $28-30 \mathrm{~cm}$ using a plow, but this method requires a lot of work. With this in mind, it was found that when corn is sown as a single crop with light watering and loosening to a depth of $8-10 \mathrm{~cm}$, the bulk density and porosity of the soil do not differ significantly and are economically viable.

In addition, the introduction of crop rotation in irrigated areas should be aimed at sowing legumes, cereals and vegetables that increase soil fertility and meet the daily needs of the population for food, mainly as secondary and catch crops.

\section{RESEARCH METHODS AND CONDITIONS}

Field experimental studies were carried out at the Samarkand Scientific and Experimental Station of the Scientific Research Institute for Cotton Breeding, Seed Production and Agricultural Technologies (PSUIAITI).

In a field experiment, it was planned to determine the influence of various methods of soil cultivation on the growth, development, yield and quality of re-crops in accordance with soil and climatic conditions, as well as changes in agrophysical and agrochemical soil properties.

The soil of the experimental site is meadow gray, the depth of the groundwater is 7-8 meters, the slope of the field is $\mathrm{i}=0.003$. In the experimental field, cotton and wheat were always planted alternately.

Experimental studies were carried out in three agility and three variants. In this case, the length of the field experimental sites was 100 meters.

Legumes were selected as secondary crops: soybeans, mung bean and beans. When preparing the soil for sowing, they used a technology based on plowing, chiseling and narrow-band tillage.

Seed germination of repeated crops was determined in each variant separately every 3 days. Phenological observations were carried out on 25 plants in each variant.

The yield and yield structure were fully defined in each variant. The weight of 1000 grains, the number of grains in the beans and the weight of the grain, the total yield were determined in the field.

During field experiments, water consumption was determined for each option (plowing, chiseling and strip tillage).

Water consumption was measured using a Cipolitti device.

To prepare the experimental plot for sowing, irrigation was carried out on July 2-4, July 10, the land was prepared for sowing, and on July 11, soybeans, mung beans and beans were sown on the experimental field.

During the period of repeated sowing in the experimental field, the plants were watered 4 times, once inter-row cultivation and once an irrigated bed was formed.

\section{RESULTS AND DISCUSSION}

After analyzing the data obtained as a result of experimental studies (table 1), it was noted that before sowing, the volumetric weight of the soil in the $0-30 \mathrm{~cm}$ layer averages $1.40 \mathrm{~g} / \mathrm{cm} 3$, and the porosity of the soil is $48.1 \%$. 
Table 1 Influence of tillage methods on bulk density and soil porosity.

\begin{tabular}{|c|c|c|c|c|c|c|c|}
\hline \multirow[t]{2}{*}{ № } & \multirow{2}{*}{$\begin{array}{c}\text { Soil } \\
\text { layer, } \\
\text { cm }\end{array}$} & \multicolumn{2}{|c|}{ On stubble } & \multicolumn{2}{|c|}{ During the growing season } & \multicolumn{2}{|c|}{$\begin{array}{l}\text { At the end of the growing } \\
\text { season }\end{array}$} \\
\hline & & $\begin{array}{c}\text { Volumetric } \\
\text { weight, } \mathrm{g} / \mathrm{cm}^{3}\end{array}$ & Porosity,\% & $\begin{array}{c}\text { Volumetric } \\
\text { weight, } \mathrm{g} / \mathrm{cm}^{3}\end{array}$ & Porosity,\% & $\begin{array}{c}\text { Volumetric } \\
\text { weight, } \mathrm{g} / \mathrm{cm}^{3}\end{array}$ & Porosity, \% \\
\hline \multicolumn{8}{|c|}{ Option 1 (plowing) } \\
\hline 1 & $0-30$ & 1,40 & 48,1 & 1,33 & 50,7 & 1,34 & 50,4 \\
\hline 2 & $30-50$ & 1,39 & 48,5 & 1,38 & 48,9 & 1,37 & 49,3 \\
\hline 3 & $0-50$ & 1,40 & 48,1 & 1,35 & 50,0 & 1,35 & 50,0 \\
\hline \multicolumn{8}{|c|}{ Option -2 (chiselizing) } \\
\hline 1 & $0-30$ & 1,40 & 48,1 & 1,35 & 50,0 & 1,35 & 50,0 \\
\hline 2 & $30-50$ & 1,39 & 48,5 & 1,38 & 48,9 & 1,37 & 49,3 \\
\hline 3 & $0-50$ & 1,40 & 48,1 & 1,36 & 49,6 & 1,36 & 49,6 \\
\hline \multicolumn{8}{|c|}{ Option -3 (strip processing) } \\
\hline 1 & $0-30$ & 1,40 & 48,1 & 1,37 & 49,3 & 1,36 & 49,6 \\
\hline 2 & $30-50$ & 1,39 & 48,5 & 1,39 & 48,5 & 1,38 & 48,9 \\
\hline 3 & $0-50$ & 1,40 & 48,1 & 1,38 & 48,9 & 1,37 & 49,3 \\
\hline
\end{tabular}

The volumetric weight of the soil in all variants before sowing was $1.39-1.40 \mathrm{~g} / \mathrm{cm} 3$, and $1.33-1.38$ for plowing; when chiselizing 1.35-1.38; with strip tillage this figure was $1.37-1.39 \mathrm{~g} / \mathrm{cm} 3$. The difference is not significant. By the end of the growing season, the difference in variants was even smaller.

In the conditions of our republic it is impossible to grow crops without watering. Water is essential during the growing season. The need for plants in water depends on climatic conditions, water capacity and soil fertility, depth of groundwater, salinity, applied agronomic techniques, biological properties of the planted plant variety.

Taking into account the above, water consumption was determined depending on the method of tillage and the needs of plants. In this case, the water consumption per second per hectare was determined. The results of water consumption, depending on the methods, are shown in Table 2.

Table 2. Water consumption depending on the processing method

\begin{tabular}{|c|c|c|c|c|c|c|}
\hline \multirow[t]{2}{*}{ № } & \multirow{2}{*}{ Parameters } & \multirow{2}{*}{$\begin{array}{l}\text { Types of } \\
\text { crops }\end{array}$} & \multicolumn{4}{|c|}{ Average water consumption, $\mathrm{m}^{3} / \mathrm{ha}$ and irrigation time } \\
\hline & & & First watering & $\begin{array}{c}\text { Second } \\
\text { irrigation }\end{array}$ & $\begin{array}{c}\text { Third } \\
\text { irrigation }\end{array}$ & $\begin{array}{c}\text { Fourth } \\
\text { irrigation }\end{array}$ \\
\hline \multirow[t]{3}{*}{1.} & \multirow[t]{3}{*}{ Plowing } & soy, & $\begin{array}{l}1134,0 \\
15 \text { july }\end{array}$ & $\begin{array}{l}1069,2 \\
27 \text { july }\end{array}$ & $\begin{array}{c}776,6 \\
22 \text { August }\end{array}$ & $\begin{array}{c}583,2 \\
20 \text { september }\end{array}$ \\
\hline & & beans & $\begin{array}{l}1134,0 \\
15 \text { july }\end{array}$ & $\begin{array}{l}1069,2 \\
27 \text { july }\end{array}$ & $\begin{array}{c}776,6 \\
22 \text { August }\end{array}$ & $\begin{array}{c}583,2 \\
20 \text { september }\end{array}$ \\
\hline & & mung & $\begin{array}{l}1134,0 \\
15 \text { july }\end{array}$ & $\begin{array}{c}972,0 \\
27 \text { july }\end{array}$ & - & - \\
\hline \multirow[t]{3}{*}{2.} & \multirow[t]{3}{*}{ Chiseling } & soy & $\begin{array}{l}1134,0 \\
15 \text { july }\end{array}$ & $\begin{array}{l}1004,4 \\
27 \text { july }\end{array}$ & $\begin{array}{c}776,6 \\
22 \text { August } \\
\end{array}$ & $\begin{array}{c}583,2 \\
20 \text { september }\end{array}$ \\
\hline & & beans & $\begin{array}{l}1134,0 \\
15 \text { july } \\
\end{array}$ & $\begin{array}{l}1004,4 \\
27 \text { july }\end{array}$ & $\begin{array}{c}776,6 \\
22 \text { August } \\
\end{array}$ & $\begin{array}{c}583,2 \\
20 \text { september }\end{array}$ \\
\hline & & mung & $\begin{array}{l}1004,4 \\
15 \text { july }\end{array}$ & $\begin{array}{c}972,0 \\
27 \text { july }\end{array}$ & - & - \\
\hline \multirow[t]{3}{*}{3.} & \multirow[t]{3}{*}{$\begin{array}{l}\text { Strip } \\
\text { processing }\end{array}$} & soy & $\begin{array}{c}874,8 \\
15 \text { july } \\
\end{array}$ & $\begin{array}{c}907,2 \\
1 \text { августа } \\
\end{array}$ & $\begin{array}{c}776,6 \\
26 \text { August } \\
\end{array}$ & $\begin{array}{c}388,8 \\
22 \text { september }\end{array}$ \\
\hline & & beans & $\begin{array}{c}874,8 \\
15 \text { july } \\
\end{array}$ & $\begin{array}{c}907,2 \\
1 \text { августа } \\
\end{array}$ & $\begin{array}{c}776,6 \\
26 \text { August }\end{array}$ & $\begin{array}{c}388,8 \\
22 \text { september }\end{array}$ \\
\hline & & mung & $\begin{array}{c}874,8 \\
15 \text { july }\end{array}$ & $\begin{array}{c}907,2 \\
1 \text { августа }\end{array}$ & - & - \\
\hline
\end{tabular}

From table 2 it can be seen that during plowing, the total water consumption is $3563.0 \mathrm{~m} 3$ / ha, while with chisel-growing and strip processing, these indicators averaged 3498.2 and $2947.4 \mathrm{~m} 3 /$ ha. At the same 
time, the water consumption during grazing and strip tillage in relation to plowing decreased by 1.82 and $17.3 \%$, respectively.

The ultimate indicator of the effectiveness of any agricultural technology is the yield obtained (table 3). With the traditional method of soil preparation (plowing and chiseling), the growing season of the re-crops was 100-105 days and ripened on November 5. In the unconventional method (strip tillage), the growing season was 90 days and the crop was harvested on October 25th. The yield data showed that the highest yield was obtained during plowing, however, with strip tillage, the yield of beans and soybeans almost did not differ from the yield obtained during plowing. Chiseling takes an intermediate position.

Table 3. Yield of repeated crops

\begin{tabular}{|c|l|c|c|c|}
\hline \multirow{2}{*}{ Option } & \multirow{2}{*}{ Tillage method } & \multicolumn{3}{|c|}{ Productivity, c / ha } \\
\cline { 3 - 5 } & & mung & beans & soy \\
\hline 1 & Plowing & 12,0 & 20,6 & 19,6 \\
\hline 2 & Chiseling & 9,0 & 18,9 & 17,7 \\
\hline 3 & Strip processing & 7,5 & 19,0 & 18,9 \\
\hline
\end{tabular}

\section{CONCLUSION}

The yield of mung bean, cultivated as a re-crop after winter cereals, depends on the method of soil cultivation. When plowing the soil, the highest yield of mung bean was obtained. The yield of beans and soybeans practically does not depend on the methods of tillage. Therefore, when cultivating these crops, it is advisable to apply strip tillage. A slight decrease in yield $(0.6-1.0 \mathrm{c} / \mathrm{ha})$ pays off by reducing material costs, including water.

\section{REFERENCES}

1. Intensification of feed production / V.N. Porojnyak. - Elbrus, 1974 .-- 81p.

2. Forage production of the steppe zone of Russia. Monograph / P.D. Shevchenko G.T. Balakay. Novocherkassk. Onyx, 2007 .-- 422 p.

3. V.P. Kondratyuk Soil cultivation for sowing cotton in Central Asia. Tashkent: Fan UzSSR, 1972, pp. 13-15.

4. Kashkarov A.K., Myakishev L., Ashurmetov I., Beshimova Sh. A thick arable layer is needed. Agriculture of Uzbekistan, 1967, no. 2, p. 17.

5. Atabaeva X.N. "Soybean is a promising crop in the irrigated conditions of Uzbekistan" Bulletin of Agrarian Science of Uzbekistan 2000 №1 23 p.

6. Yormatova D.E. Soy. Samarkand, 1990.

7. I.T. Karabaev, F.M.Xasanova, N.M.Ibragimov, A.M.Mansurov. Influence of technological processing and mulching of soil on water consumption and consumption of water on creation of units urojaya cotton. Maslichnye kultury

8. MM Hasanov, DR Mavlyanov - The effectiveness of methods and timing of tillage after winter wheat. International scientific-practical conference "Sources of high yields and water-saving technologies in agriculture." Tashkent 2010

9. Iminov AA, Khalikov BM, The effect of secondary crops on the amount of nutrients in the soil. Collection of articles of the Society and Congress of Soil Scientists and Agrographers of Uzbekistan.-Samarkand, TAITDI. 2005.- B.257-258.

10. FM Hasanova, IT Karabaev - Influence of replanted corn on soil agrophysical properties. International scientific-practical conference "Sources and water-saving technologies for the production of abundant crops in agriculture." Tashkent 2010 